

\title{
Equity and cost-effectiveness of multilateral adaptation finance - are they friends or foes?
}

\author{
Martin Stadelmann*, Åsa Persson+, Izabela Ratajczak-Juszko ${ }^{\S}$, Axel Michaelowa*
}

\begin{abstract}
This paper analyses potential criteria to allocate international funding for adaptation to climate change, as a response to one of the main governance challenges of international adaptation funding - the prioritization of project proposals given scarce funding. Based on the review of the equity and cost-effectiveness literature and relevant policy documents, we identify three indicators for equity (vulnerability level, poverty, number of beneficiaries), and three indicators for cost-effectiveness (economic savings in absolute and relative terms, human lives saved). Applying these simple indicators to information provided in 16 project documents considered by the Adaptation Fund Board (AFB) in 2011, we find that projects approved by the AFB rank high according to one cost-effectiveness indicator (absolute economic savings), while they rather rank low according to all equity and further costeffectiveness indicators. Furthermore, we analyse whether 'equity' and 'cost-effectiveness' are two contradicting principles, or if ways can be found to reconcile both principles in multilateral adaptation finance. We conclude from both theory and the 16 analysed projects that a pure economic definition of cost-effectiveness is in contradiction with equity but tradeoffs between equity and cost-effectiveness can be limited if relative wealth savings, and other indicators, e.g. human health, are used as indicator for cost-effectiveness.
\end{abstract}

Keywords: Climate change, Adaptation, Finance, Equity, Cost-effectiveness

\footnotetext{
* Center for Comparative and International Studies \& Department of Political Science, University of Zurich. Corresponding Author: martin.stadelmann@pw.uzh.ch, Tel. +4144634 5091

+ Stockholm Resilience Centre, Stockholm University \& Stockholm Environment Institute

$\S$ Global Cities Research Institute, RMIT University, Melbourne
} 


\section{List of Acronyms}

AF-Adaptation Fund

AFB-Adaptation Fund Board

CDM- Clean Development Mechanism

UNFCCC-United Nations Framework Convention on Climate Change

\section{Table of contents}

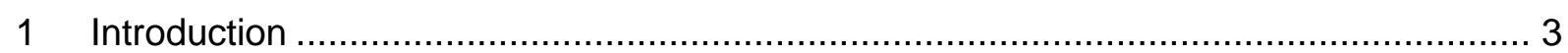

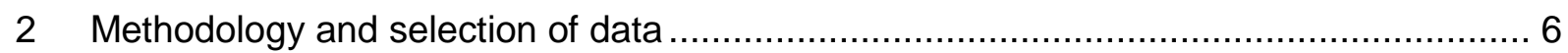

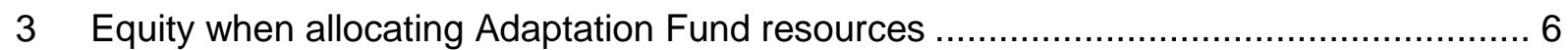

4 Cost-Effectiveness when allocating Adaptation Fund resources .................................15

5 Equity and cost-effectiveness - are they friends or foes? .......................................19

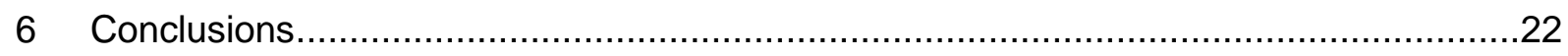

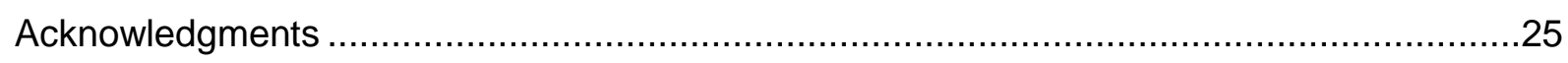

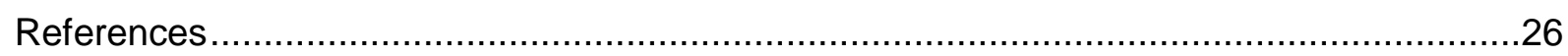

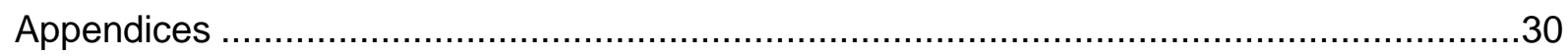




\section{Introduction}

Multilateral climate adaptation finance has been one of the most dynamic and transformational elements within the whole international climate regime. The outcomes of UN climate change negotiations in recent years contributed to a paradigm shift in international climate policy. Climate change adaptation was recognised as equally important to climate change mitigation, which is formally the primary objective of the UNFCCC. However, explicit consideration of adaptation under the international regime is still in its infancy and it is often questioned if the needs of developing countries are adequately addressed (Pielke et al., 2007; Stern, 2007; Müller, 2008; Ayers and Dodman, 2010).

Among the different multilateral funds that finance concrete adaptation projects and programmes in developing countries, the Adaptation Fund (AF) stands out because of two reasons: non-governmental funding sources and direct access for developing countries. First, the AF obtains its primary source of finance through a levy on projects under the Clean Development Mechanism (CDM), a market-based instrument under the Kyoto Protocol. The AF can be characterised as a form of 'intergovernmental grant system' mandated to (Ratajczak-Juszko and Feaver, 2011). Second, a novel element introduced by the fund is a 'direct access modality' empowering governments of developing countries to directly submit proposals at the AF, without having to use a multilateral organization such as UNDP and the World Bank as intermediary.

While in principle, "developing country Parties to the Kyoto Protocol that are particularly vulnerable to the adverse effects of climate change" (AFB, 2010b) can access the AF, prioritization among eligible countries and projects remains unclear. While the decisions on the allocation of resources of the Fund "shall take into account" certain review criteria, e.g. vulnerability of host country, cost-effectiveness, consistency with national policies (see AFB, $2012 b)$, there are no clear guidelines at what threshold level these criteria are deemed to be fulfilled and how it is measured. Therefore, the Adaptation Fund Board (AFB) secretariat has recommended that the AF should prepare a guidance document on how project proponents should describe the cost-effectiveness and consultative process part of the project proposals (AFB, 2011a)

Apart from handling these general uncertainties on project eligibility criteria, the AFB currently has to consider how to deal with a situation where funding requests for eligible 
projects exceed the amount of available funding (AFB, 2012a) ${ }^{1}$. Using the first-come-firstserve criterion for allocation of funding, as currently applied, will become more and more questionable, given that this will provide an incentive to submit proposals as early as possible.

Given the emerging need for the AFB to prioritize among project proposals, this paper considers which criteria could be used for prioritization. In the literature on adaptation policy, we find primarily a discussion of two potential goals or normative criteria of adaptation policy $^{2}$ : First, equity/fairness, or the equitable and fair treatment of countries and persons (e.g. Thomas and Twyman, 2005; Paavola and Adger, 2006; Dellink et al., 2009; Persson and Remling, forthcoming), and second, cost-effectiveness or efficiency, the generation of the a maximum benefit for a given level of resources (e.g. Mendelsohn, 2000; UNFCCC, 2010a; Fankhauser and Burton, 2011; Stadelmann et al., 2011). To date, only Persson and Remling (forthcoming) have both discussed efficiency and equity rationales for allocation of AF resources (see Figure 1). However, they have not analyzed if efficiency/costeffectiveness and equity are contradictory or complementary principles, which is an open debate in other policy fields (see e.g. Okun, 1975; Le Grand, 1990; Blank, 2002; Dietz and Atkinson, 2010)

\footnotetext{
${ }^{1}$ This situation has occurred as the AFB decided to cap the funding flowing through multilateral organizations to $50 \%$ of all AF funding in December 2011.

${ }^{2}$ Further normative criteria for climate change adaptation are legitimacy (Adger et al., 2005), and sustainability (Eriksen et al., 2011). For simplicity, we focus on the equity and cost-effectiveness here.
} 


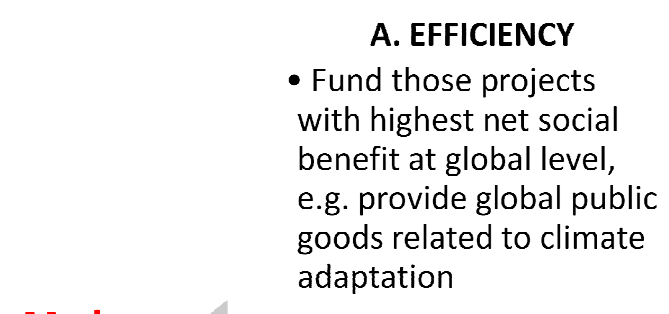

Market

failure

\section{B. EFFICIENCY}

- Fund those projects with highest net social benefit at national or sub-national level

\section{EQUITY}

- Fund countries that are

'particularly vulnerable':

i. proportional to level of vulnerability

ii. proportional to population

iii.as equal lump sums

Distributive

\section{EQUITY}

- Fund projects benefiting particularly vulnerable sub-national groups:

i. proportional to local level of vulnerability

ii. proportional to population affected Local

Source: Persson \& Remling (forthcoming)

Given the importance of equity and cost-effectiveness in the adaptation policy literature, we will assess potential indicators for both equity and cost-effectiveness, and how they could be useful as criteria for prioritization of adaptation funding. As a further step, we will analyze if equity and cost-effectiveness are contradictory principles and if policymakers will face tradeoffs if they want to prioritize adaptation projects considering both goals, or if we find synergies. We conduct our analysis on both a theoretical as well as an empirical level. In the empirical part, we analyze data from the AF as major multilateral funding institution. We use 16 adaptation funding project proposals from the year 2011 to analyze how well projects approved by the AFB de facto perform according to our equity and/or cost-effectiveness indicators, as compared to project proposals that were not approved3. Furthermore, we can assess whether aiming at both equity and cost-effectiveness would have created trade-offs in case of the 16 projects. Given the small sample, it is clear that the empirical basis is not sufficient for robust quantitative testing of hypotheses but rather helps to back up our theoretical analysis.

\footnotetext{
${ }^{3}$ The Adaptation Fund Board does not "reject" project proposals but rather sends proposals back to the project proponent to reconfigure the project
} 


\section{Methodology and selection of data}

Each of the following chapters will have the same structure: definition of the key terms (equity and cost-effectiveness), short review of the literature, and analysis of relevant AFB documents and finally analysis of concrete AF projects.

For the last step, we have selected a sample of 16 out of 27 project documents considered by the AFB in 2011, covering projects discussed at AFB13 and AFB15. While the selection has not been random, these 16 projects represent $80 \%$ of approved funding and $75 \%$ of all implementing agencies submitting projects in 2011 (see Table 1). The project documents were downloaded from the "AFB meeting documents" section on the AFB (2011c, 2011b) webpage. A full list of projects in the sample, with implementing agencies, stated number of beneficiaries and funding amounts is provided in Appendix 1.

Table 1: Analyzed projects compared to all AFB projects considered in 2011

\begin{tabular}{|c|c|c|c|c|c|c|}
\hline & \multicolumn{2}{|c|}{ Considered by AFB in 2011} & \multicolumn{3}{c|}{ Approved by AFB in 2011} \\
\hline & $\begin{array}{c}\text { \# of } \\
\text { proposals }\end{array}$ & $\begin{array}{c}\text { Funding } \\
\text { (Million } \\
\text { USD) }\end{array}$ & $\begin{array}{c}\text { \# of Imple- } \\
\text { menting } \\
\text { agencies }\end{array}$ & $\begin{array}{c}\text { \# of } \\
\text { proposals }\end{array}$ & $\begin{array}{c}\text { Funding } \\
\text { (Million } \\
\text { USD) }\end{array}$ & $\begin{array}{c}\text { \# of Imple- } \\
\text { menting } \\
\text { agencies }\end{array}$ \\
\hline ALL & 27 & 187.1 & 8 & 13 & 85.6 & 4 \\
\hline SAMPLE & 16 & 117.0 & 6 & 10 & 68.1 & 4 \\
\hline$\%$ & $59 \%$ & $63 \%$ & $75 \%$ & $77 \%$ & $80 \%$ & $100 \%$ \\
\hline
\end{tabular}

\section{Equity when allocating Adaptation Fund resources}

Equity as a principle for allocating scarce funds is complicated to define, in general. An additional complication in the case of the AF is the fact that we are dealing with equity, or distributive justice, at two levels; between countries and between projects.

It is currently unclear which level matters more in the allocation of funding, as some review criteria in the Operation Guidelines are equity-related but their application is less straight forward. We return to this issue below, but first we review alternative interpretations of equity in the theoretical literature. 
The relational property of equity has been captured in social psychology, primarily equity theory as developed by Adams (1965). This theory understands equity as distribution of resources perceived as fair by both relational partners. It posits that an individual will consider he/she is fairly treated when the following condition holds:

$$
\frac{\text { individual's outcomes }}{\text { individual's inputs }_{\text {ind }}}=\frac{\text { relational partner's outcomes }}{\text { relational partner's inputs }}
$$

Translating this theory to the adaptation finance context, we could consider developing countries eligible for adaptation finance as 'individuals' in this case ${ }^{4}$. Having a common pool of resources to share, they would arguably only perceive the allocation of funds ${ }^{5}$ (outcomes) as equitable in case they are uniformly proportional to some condition (input). In the case of the AF, this condition is most often thought of as level of vulnerability (Klein, 2009; Horstmann, 2011; Klein and Möhner, 2011). ${ }^{67}$ We shall see below that the operationalisation and measurement of level of vulnerability is the most common problem when applying equity principles and has challenged the AFB. It should also be emphasised that perceived fairness of a particular distribution of resources depends not only on the transfers and their underlying principle, but also on the procedures followed, e.g. with reference to ensuring representativeness and consistency in decision-making (Leventhal, 1980; Adger et al., 2007). Furthermore, not only intra- but also intergenerational justice is to be considered in the context of adaptation (Tol et al., 2004) In this paper we focus on distributive and intragenerational rather than procedural and intergenerational justice, however. The design of the AF makes it very likely that procedural justice can be achieved, at least at an international and national level, and intergenerational justice is a topic beyond the scope of this paper.

Approaching equity from a normative rather than positive perspective, some alternative principles have been developed in political theory. Duus-Otterström and Stripple (2011) review three alternative principles of justice in relation to allocating adaptation finance, which

\footnotetext{
${ }^{4}$ This country-level focus of our equity discussion is related to the structure of international relations and somehow neglects that there are relevant distributional issues between people living in one country, and that an equitable allocation of funds to countries does not assure equitable distribution of these funds within each country, see the discussion below.

${ }^{5}$ One could also see "increased utility" and not "allocation of funds" as outcome. For simplicity, we assume a linear relation here.

${ }^{6}$ The primacy of vulnerability as the basis for allocating funds can be seen in the decision (1/CMP.3) establishing the Adaptation Fund, where 'particular vulnerability' is defined as the key eligibility criterion for developing country parties to the Kyoto Protocol to receive funds. Vulnerability is further mentioned in other COP decisions and 'level of vulnerability' stated as the first in a series of variables that should be taken into account when allocation decisions are made, according to the Strategic Priorities, Policies and Guidelines of the Adaptation Fund.

${ }^{7}$ Note that proportionality is not applicable if we interpret 'particular vulnerability' as a binary category rather than an interval variable.
} 
we consider here at the level of countries rather than projects or individuals. First, equality, if referring to (i) equal funds to all countries, would not change current inequity. If referring to (ii) an allocation so that all countries become equally (in)vulnerable, it is seen as unrealistically costly or flawed in that it could be interpreted as, in principle, allowing for a 'levelling-up'8 of vulnerability. The applicability of this second interpretation of equality (i.e., equal vulnerability) is limited in the context of the AF since the allocation is not a one-off event, but a series of decisions informed by previous decisions, and since time lags in affecting vulnerability levels would make it difficult to determine when vulnerability is equal. Furthermore, a 'levelling-up’ scenario does not appear to be politically acceptable.

Second, the leximin principle (see also Kolm, 1996; Paavola and Adger, 2006) avoids the 'levelling-up' problem, by stipulating a step-wise move down the vulnerability ladder; resources are first allocated so that the worst-off become as well off as the second-to-worst off, and if resources remain, as well off as the third-to-worst off, etc. Vulnerability would thus be the currency also for applying this principle. Duus-Otterström and Stripple claim that this principle, while appealing, would be prohibitively resource-demanding. Arguably, though, this depends on the choice of vulnerability indicator/index and the incidence of countries on that scale. Existing indices (see below) suggest that country scores are relatively dispersed, which means that the initial steps up the ladder need not be prohibitively costly, in principle ${ }^{9}$. Ratajczak-Juszko and Feaver (2011) propose an approach for the Adaptation Fund that would not disburse to the most vulnerable to let them catch-up (as in leximin) but would 'level-down' vulnerability in a series of repeated allocation decisions. Arguing that equity should be directly related to 'need' (vulnerability) and inversely related to 'capacity' (adaptive capacity), they propose the following formula for determining transfers from the Fund:

$$
T R i=N i-C i
$$

Where $T R i$ is the transfer from the AF to country $i, \mathrm{Ni}$ is need due to vulnerability, and $\mathrm{Ci}$ is capacity to adapt. With this reasoning, funding would thus be proportional to 'net vulnerability'.

The third candidate principle reviewed by Duus-Otterström and Stripple (2011) is utilitarianism, which stipulates the maximization of utility or 'happiness' as moral criterion for governing the society (Mill, 1863), a principle that has become the foundation of 'economic efficiency'. As commonly criticised (see e.g. Parfit, 1997), it does not distinguish between

\footnotetext{
${ }^{8}$ This means that vulnerability is not reduced (which one would expect to be a goal for adaptation funds) but that in some countries it would be increased.

${ }^{9}$ To illustrate, reducing the vulnerability of one country (e.g. Guinea Bissau) to the level of the second most vulnerable (e.g. Honduras) would most likely cost less than a scenario of reducing the vulnerability of ten equally vulnerable countries to the level of the eleventh country.
} 
benefits accruing to the most vulnerable and those accruing to less vulnerable actors and is therefore often seen as inequitable. Furthermore, utility is often measured by willingness-topay, which means that benefits of poorer and, therefore, often more vulnerable countries are underrepresented. This could be addressed, however, through weighting of benefits according to the vulnerability of countries or communities. ${ }^{10}$

Clearly, all principles rely on the currency of vulnerability and the same operationalisation and measurement challenges are faced. The construction of vulnerability indicators or indices, measured at national or sub-national levels, has been strongly contested in the academic community. For example, Hinkel (2011) and Klein (2009) argue that vulnerability is a too complex and subjective phenomenon to lend itself to 'measurement' and comparison across countries. Equally important, they argue that it is misleading that science could help develop and aggregate indicators, since it is an inherently political issue. Füssel (2010) argues that a generic index would not be appropriate, whilst sector- or hazard-specific criteria could help guide funding allocation. However, experiences with mitigation have shown that it was possible to agree on indicators such as Global Warming Potentials with a specific time horizon even under a consensus rule, and thus an agreement on vulnerability indicators seems not generally impossible.

Researchers have proposed country indices for vulnerability and adaptive capacity (see Buys et al., 2009; Barr et al., 2010; Global Adaptation Institute, 2011; Wheeler, 2011). Comparing the first three indices for 'impact vulnerability', they all include change in agricultural yield and exposure to sea level rise, whereas two of the three include health impacts and population sensitivity to disasters. In addition to their impact vulnerability index, Barr et al. (2010) have also developed an 'adaptive capacity' index which includes six indicators related to age structure of the population, access to credit, income inequality, governance, literacy and education rates. Our initial analysis suggests that country scores are not particularly robust across indices, but this requires further research (Persson and Remling, forthcoming). As further challenge when allocating funding, these vulnerability indices have been calculated only at a country level. In relation to the issue of the two levels with which the AF is concerned, national level and project level, it is unclear whether the observed variation between country scores is higher or lower than variation between regions within a country.

\footnotetext{
${ }^{10}$ Note that (Duus-Otterström and Stripple, 2011) argue that an alternative principle to weighted utilitarianism is prioritarianism, whereby the weighting is not only instrumental to maximising net welfare but the weights have a moral priority.
} 
The second major problem is thus whether the AF should aim for equity among countries, or should it aim for equity among projects or sub-national entities? The principles above assume that there is only one type of worthy recipient to be compared (for example, countries) rather than two types, or levels, or recipients (for example, countries and subnational projects).

Given these major challenges - various equity definitions, vulnerability indices and two levels - which equity-related principles did the AFB use so far? Starting from the eligibility criteria on the country level ${ }^{11}$ specific considerations are to be made when allocating resources among eligible countries, see Article 16 of the Operation Guidelines (AFB, 2010b), among which we find three criteria that are clearly equity-related ${ }^{12}$ : (a) Level of vulnerability [...], (c) Ensuring access to the fund in a balanced and equitable manner [...] and (g) adaptive capacity to the adverse effects of climate change."

In relation to the first equity-related principle, the 'level of vulnerability', so far, the AFB has chosen to not define vulnerability more precisely, including operationalising it into indicators or an index. The issue has been discussed at several meetings. In June 2010, the AFB concluded that "no one measure could be applied and the vulnerability of a country had to be determined by each country itself" (AFB, 2010c). Horstmann (2011) argues that it is unlikely that the AFB members would adopt a more precise definition which may exclude countries in their constituencies and that the current situation where it is up to the country itself to interpret vulnerability is actually in line with the country-driven approach, another principle stipulated for the AF. In the absence of a standard methodology, it is thus not clear whether or how the AFB applies the 'particular vulnerability' (binary category) or 'level of vulnerability' (interval) criteria. The problem is further confounded by the fact that the review process and its documentation are not open to the public.

The second equity-related principle stipulated for the AF is 'access to the fund in a balanced and equitable manner for eligible countries'. ${ }^{13}$ This principle has been operationalised to some extent. A document on 'initial funding priorities' was under discussion in the AFB for a considerable amount of time. An interim version considered regions, LDC/SIDS status and the status as ODA recipient as criteria to decide on the allocation of funds. In the end, a

\footnotetext{
${ }^{11}$ See Article 12.8 of the Kyoto Protocol and Decision 10/CP.7.

${ }^{12}$ We consider the following two criteria as rather effectiveness than equity-oriented (d) Lessons learned in project and programme design and implementation to be captured [..."(e) Securing regional co-benefits to the extent possible, where applicable", while a further criterion "b) Level of urgency and risks arising from delay" is seen here as captured by an adequate vulnerability assessment ${ }^{13}$ See Decision 5/CMP.2
} 
uniform cap of $\$ 10$ million per country was set. ${ }^{14}$ This principle is a weak version of the equity principle 'equality', in the sense that all entities should have the same maximum amount of resources available.

Finally, the strategic priorities of the AF state that 'special attention shall be given by eligible Parties to the particular needs of the most vulnerable communities'. ${ }^{15}$ This 'priority' addresses sub-national equity in some sense, but is clearly not a requirement to demonstrate that the project will benefit the most vulnerable community in a particular country. Nor does it give any guidance on how community-level vulnerability should be compared across countries.

Against this background of theory and AFB practices, we formulate here a series of simple and operational equity indicators to demonstrate how they correspond with funding decisions actually taken. We describe how they apply to the level of countries and/or individuals.

The first principle is equality, which can be both understood as equality between countries and equality between individuals. First, we look at equality between countries, in the sense that all developing countries get an equal amount of funding. As stated above, this principle can be considered inequitable when initial conditions (e.g. population, national income, vulnerability) vary, which is most often the case. Since the AFB has adopted a uniform national cap of $\$ 10$ million and project proposals submitted so far ask for similar amounts (between 5-10 million, see Appendix 1), we can argue that this principle is de facto followed to a considerable extent. We examine below, though, whether funding decisions made (implicitly) adhere to other equity principles simultaneously.

While the equal funding per country can be justified on the basis that countries (rather than individuals) are Parties to the UNFCCC and that they are equal Parties, a variation of this principle could be country funding based on equal funding per capita, which is a proxy for equality between individuals. Equality could then be estimated by the variance of the number of beneficiaries per dollar of funding between countries, the lower the variance, the more equal the funding will be distributed. Given that national population of the eligible countries differs by 5-6 orders of magnitude, it is clear that this principle would imply a significantly different allocation compared with country-level equal funds. Minimizing the variance of the

\footnotetext{
${ }_{15}^{14}$ Decision B.13/23

${ }^{15}$ See Strategic priorities, policies and guidelines of the Adaptation Fund approved by the CMP (Decision 1/CMP.4). The wording of "vulnerable communities" can also be interpreted as a replacement of "vulnerable countries", on which no political agreement has been reached.
} 
number of beneficiaries can be contested on several grounds, e.g. a tendency to spread out resources so thinly that there will not be any significant benefit, potential mismatch between number of beneficiaries and real benefits, or the low data quality on beneficiaries ${ }^{16}$. While this equality indicator does somehow disregard the criterion of 'particular vulnerability' of countries, it is already a bit closer to vulnerability than equal funding per country.

The second principle, we formulate here is support for the most vulnerable, in that more vulnerable countries should have priority access to the Adaptation Fund. This principle is inspired by the equality (achieving equality of vulnerability) and leximin principles above. Strict application of these is not possible due to the time lag in observing vulnerability and the fact that the national cap of $\$ 10$ million prohibits differentiation of grants awarded. We test this vulnerability principle by taking the vulnerability index of Barr et al. (2010) as an example and by doing a sensitivity analysis by applying two other indices (Buys et al., 2009; Global Adaptation Institute, 2011).

Using vulnerability indices imply several problems. First, these indices do not cover all eligible countries; the Barr index covers at least all but one country in our sample. Second, the variation in country rankings on the three vulnerability indices suggests that they are indeed sensitive to choice of indicator and data used. Third, the vulnerability indices are very difficult to understand for the general public and even policymakers, as most of them are composed of several sub-indicators. Given these challenges of vulnerability indices, we also apply the equality principle in relation to GDP per capita, assuming that allocating funding to the poorest countries will reduce inequality. While the GDP per capita indicator falls short of including all relevant assets of individuals and is also a sub-optimal proxy for climate vulnerability, it is considered relevant here as a simple, well understandable indicator for poverty and low development, which is relevant in the AFB context where LDC status has been discussed as a basis for priority access ${ }^{17}$.

Table 2 shows which projects in the sample would have to be selected according the three ${ }^{18}$ proposed equity criteria. Some projects are consistently among the five highest (e.g. Mali,

\footnotetext{
${ }^{16}$ First, the number of beneficiaries says nothing about the level, quality and directness of benefits, which make comparison difficult. For example, an ecosystem-based adaptation may indirectly benefit many thousands of users of a resource, but in a marginal way, while some adaptations could directly ensure livelihoods of a smaller group of individuals. Second, the estimates of number of beneficiaries reported in proposals are uncertain and no consistent methodology is used.

${ }_{17}^{17}$ See decision B.13/23

${ }^{18}$ We neglect "equality between countries" here as this would simply mean that all countries receive the same level of funding. In this sense, the principle is not useful for prioritization of project proposal.
} 
Mauritania) or five lowest ranked projects (e.g. Belize, Cook Islands, Mauritius and Uruguay), while others have ambiguous rankings.

Table 2: Ranking of Adaptation Fund projects according to equity indicators

\begin{tabular}{|c|c|c|c|c|c|c|c|}
\hline $\begin{array}{l}\text { Equity } \\
\text { indicator }\end{array}$ & \multirow{2}{*}{\multicolumn{2}{|c|}{$\begin{array}{c}\text { Support for the } \\
\text { most vulnerable } \\
\text { Vulnerability index, } \\
\text { rank }(1=\text { most } \\
\text { vulnerable })\end{array}$}} & \multicolumn{2}{|c|}{$\begin{array}{l}\text { Support for the } \\
\text { poorest countries }\end{array}$} & \multicolumn{2}{|c|}{$\begin{array}{l}\text { Equal funds per } \\
\text { capita }\end{array}$} & \multirow{3}{*}{$\begin{array}{l}\text { Appro- } \\
\text { ved by } \\
\text { the } \\
\text { AFB? }\end{array}$} \\
\hline \multirow[t]{2}{*}{ Measure } & & & \multicolumn{2}{|c|}{ Low GDP per capita } & \multicolumn{2}{|c|}{$\begin{array}{l}\text { No. of beneficiaries } \\
/ k \$ \text { of funding }\end{array}$} & \\
\hline & $\begin{array}{l}\text { Absolute } \\
\text { Value }\end{array}$ & RANK & $\begin{array}{l}\text { Absolute } \\
\text { Value }\end{array}$ & RANK & $\begin{array}{l}\text { Absolute } \\
\text { Value }\end{array}$ & RANK & \\
\hline Belize & 78 & 12 & 4349 & 12 & 0.8 & 13 & No \\
\hline Cook Islands & - & & 12325 & 15 & 1.1 & 12 & Yes \\
\hline Ecuador & 57 & 10 & 4352 & 13 & 26.8 & 4 & Yes \\
\hline Egypt & 40 & 6 & 2922 & 9 & 13.7 & 9 & Yes \\
\hline Eritrea & 3 & 1 & 473 & 2 & 9.9 & 10 & Yes \\
\hline Georgia & 101 & 14 & 3098 & 11 & 37.6 & 2 & Yes \\
\hline Madagascar & 45 & 8 & 428 & 1 & 20.5 & 6 & Yes \\
\hline Mali & 30 & 4 & 796 & 4 & 46.9 & 1 & No \\
\hline Mauritania 1 & 8 & 2 & 1227 & 5 & - & & No \\
\hline Mauritania 2 & 8 & 2 & 1227 & 5 & 37.5 & 3 & No \\
\hline Mauritius & 96 & 13 & 8519 & 14 & 0.3 & 15 & Yes \\
\hline Papua New G. & 44 & 7 & 1712 & 8 & 17.2 & 7 & No \\
\hline Samoa & 76 & 11 & 3049 & 10 & 6.9 & 11 & Yes \\
\hline $\begin{array}{l}\text { Solomon } \\
\text { Islands }\end{array}$ & 56 & 9 & 1457 & 7 & 22.6 & 5 & Yes \\
\hline Tanzania & 38 & 5 & 550 & 3 & 16.3 & 8 & Yes \\
\hline Uruguay & 128 & 15 & 14672 & 16 & 0.5 & 14 & Yes \\
\hline Source & Barr et & 2010 & IMF & 111) & Project & uments & \\
\hline
\end{tabular}

Has the AFB rather approved projects that our proposed equity principles would suggest for funding? It seems the opposite has happened. The Spearman rank-ordered correlation coefficient between funding approval and equity principles (Table 3 ) shows that the AFB has, at least in 2011, rather selected projects in countries with low vulnerability (so a high 
vulnerability rank), high income per capita ${ }^{19}$ and a low number of beneficiaries. However, the sample is small, so only the negative correlation between vulnerability and approval is significant at the $10 \%$ level. Interestingly, the negative correlation between vulnerability and approval does not depend on the index chosen; according to all indices, the AFB has rather selected projects in countries with low vulnerability (see Appendix 3)

Table 3: Correlation between project approval and equity criteria

\begin{tabular}{|l|c|c|c|c|}
\hline & Approval & $\begin{array}{c}\text { Vulnerability } \\
\text { rank (Barr } \\
\text { et al. 2010) }\end{array}$ & $\begin{array}{c}\text { GDP per } \\
\text { capital }\end{array}$ & $\begin{array}{c}\text { No. of } \\
\text { beneficiaries }\end{array}$ \\
\hline Approval & 1.00 & & & \\
\hline $\begin{array}{l}\text { Vulnerability rank (Barr et } \\
\text { al. 2010) (low=vulnerable) }\end{array}$ & $0.44^{*}$ & 1.00 & & \\
\hline GDP per capita & 0.20 & $0.81^{* * *}$ & 1.00 & \\
\hline No. of beneficiaries & -0.23 & $-0.38^{*}$ & $-0.51^{*}$ & 1.00 \\
\hline
\end{tabular}

Spearman product moment correlation coefficients

${ }^{*}=$ significant at 0.1 level, ${ }^{* *}=$ significant at 0.05 level, ${ }^{* *}=$ significant at 0.01 level,

$\mathrm{N}=16$ (except for GDP $(\mathrm{N}=16)$

This equity analysis has severe limitations. Apart from the selection of equity indicators, which imply important value judgements, we have a general limitation connected to the level of analysis: the indicators applied are on a national level but it would be relevant here to capture the issue of sub-national equity, or equity between individuals, considering that allocation is primarily made to projects rather than countries and that attention should be paid to the needs of 'most vulnerable communities'. Note that comparison of projects, based on the vulnerability of the targeted communities, within a country is in a sense delegated to the national governments of eligible countries, who are effectively responsible for making sure that the national cap is used in the best way (according to criteria of their choice). The AFB can instead compare projects across countries. The vulnerability principle could be applied in theory, but currently there is a lack of comparable vulnerability indices and data at subnational level. A utilitarian approach with weighted benefits could also be applied in theory, but lack of quantified benefit estimates in the proposals prevents this. Some basis for assigning weights would also need to be developed, such as differential vulnerability of the target communities.

\footnotetext{
${ }^{19}$ The correlation between approval and GDP per capita in the project country even persists when we extend the sample to all 27 project documents considered by the 2011.
} 


\section{Cost-Effectiveness when allocating Adaptation Fund resources}

Cost-effectiveness is a measure for the extent to which a policy can achieve an objective per unit of social costs - a common policy indicator in the climate change mitigation field (Gupta et al., 2007). Like its mitigation counterpart, also adaptation policy has to correctly assess costs but the real challenge lies in the determination of the "effectiveness" part, for two reasons.

The first challenge in assessing "cost-effectiveness" is that uncertainty prevails in the extent of climate change (Solomon et al., 2007), its impact on human and ecosystems (Parry et al., 2007; Parry et al., 2009) and the benefits of adaptation measures (Adger et al., 2007). This means that some interventions may prove to be more or less beneficial than anticipated, or a measure may even have a negative impact, implying "maladaptation" (Barnett and O'Neill, 2010). Therefore, flexible approaches and soft measures with long-term benefits may be most appropriate for adaptation (Hallegatte, 2009; Fankhauser and Burton, 2011). Unfortunately, the benefits of soft and flexible interventions are difficult to predict. The second issue is that "effectiveness" indicators for adaptation have not yet been agreed (Adger et al., 2007; UNFCCC, 2010b). Typically, the (avoided) climate impacts are quantified for adaptation interventions, both in welfare terms (e.g. Tol et al., 1998) or non-monetary terms such as crop yields (e.g. Lobell et al., 2008), exposed population or health (e.g. Costello et al., 2009).

Given the missing agreement on cost-effectiveness measurement in the academic literature, political definitions in AFB documents may help. The AFB (2010a) has, similar to other development agencies, set up a result framework, where it defines desired outputs, outcomes, impact and goal of adaptation interventions ${ }^{20}$. The reasoning is that immediate project outputs should lead to short- and mid-term outcomes and finally to impacts and achievement of the goal. Given that outputs (e.g. trained people) and outcomes (e.g. built dams) are intermediary results, the measure ultimately of interest from an cost-effectiveness point of view is the "impact". The AFB has very vaguely defined the desired impact as "increased resiliency at the community, national, and regional levels to climate variability and change" without further defining an indicator for it. Also the goal of the AFB interventions

\footnotetext{
${ }^{20}$ Following the standard OECD (2002) definitions, outputs are the "products and services which result from the completion of activities", outcomes are "intended or achieved short-term and medium-term effects of an intervention's output" and impacts are longer term results of interventions.
} 
does not reveal much more, apart from the focus on particularly vulnerable countries ${ }^{21}$. The AFB project proposal form (AFB, 2012c) and the project review criteria (AFB, 2012b) are even less specific by mentioning "Does the project provide economic, social and environmental benefits, with particular reference to the most vulnerable communities?" and "Is the project cost-effective?" These very generic sentences have led to a very heterogeneous way of describing cost-effectiveness in the 16 projects we assessed.

We understand cost-effectiveness of adaptation projects, here, in terms of the ultimate effect of AFB projects per USD invested, to improve people's well-being by helping them to cope with climate change. Therefore, we are not primarily interested in intermediate outcomes (e.g. capacity building, regulatory change) of AFB projects themselves but in their ultimate contribution to improve well-being of persons and countries ${ }^{22}$.

As neither the academic literature nor AFB policy documents have been clear which indicator captures cost-effectiveness of interventions, we will rely on a set of three cost-effectiveness indicators that try to proxy cost-effectiveness: absolute wealth, relative wealth and health saved per USD of spending (as proposed by Stadelmann et al., 2011). While these three indicators involve value judgments and simplify the overall set of potential adaptive benefits $^{23}$, we can argue that they reflect the most important features in both the literature (monetary and non-monetary benefits) as well as AFB documents (vulnerability ${ }^{24}$; economic, social and environmental benefits), as we will explain in the following.

The first indicator is Saved Wealth (absolute), defined as the monetised assets saved by adaptation interventions. Saved Wealth reflects economic value as the standard indicator used by economists to conduct cost-benefit analysis of adaptation interventions (Fankhauser and Tol, 1998; ECAWG, 2009; Moench et al., 2009). It also represents the "economic benefits" demanded in the AFB's project review criteria (AFB, 2012b). The philosophical background of measuring benefits through monetary terms is the stipulation in Utilitarianism that maximizing the sum of personal utilities is the desirable social goal, while utility can be

\footnotetext{
21 "Assist developing country Parties to the Kyoto Protocol that are particularly vulnerable to the adverse effects of climate change in meeting the costs of concrete adaptation projects and programs, in order to implement climate resilient measures" (AFB, 2010a)

${ }_{22}$ Given that both climatic hazards and human development are uncertain, estimating ultimate costeffectiveness will be very challenging. If it proves to be impossible to estimate a range for costeffectiveness, then reliance on outcome indicators may be preferable.

${ }^{23}$ It is clear that ultimately a political decision will be needed on the indicators for "adaptive benefits", whether is on the international, the national or the community level. How this decision process shall be governed is to be explored.

${ }^{24}$ One may simply see "reducing vulnerability" as main "cost-effectiveness" indicator (see discussion on equity and cost-effectiveness synergies below). However, both the literature and AFB documents mention cost-effectiveness indicators beyond vulnerability, so we will keep the analysis broader.
} 
measured by willingness to pay. Using Saved Wealth as the only indicator would have two major drawbacks: first, non-monetised benefits, including some of the social ${ }^{25}$ and environmental benefits asked for by the AFB (2012b) would not be included. Second, willingness to pay is dependent on the existing wealth level, so Absolute Wealth Saved will probably favour countries with high income and high capacity to adapt and, therefore, is not representing the most vulnerable countries. Therefore, two other indicators are used: Saved Health and Saved Wealth (relative) ${ }^{26}$.

The second indicator is Saved Health, measured in Disability Adjusted Life Years Saved (DALYs), an indicator systematically utilized by the World Health Organization (WHO, 2010). The DALY indicator is mainly used because monetization of saved lives is ethically challenging and has sparked intensive debate in the past (Fankhauser and Tol, 1998). Already Fearnside (1998) suggested separating human lives and property values when assessing climate change impacts. Furthermore, Saved Health may be a good proxy for reduced vulnerability and it does not differ between lives of rich and poor persons.

The third indicator is Saved Wealth in relative terms (percentage of personal wealth saved, multiplied with the number of beneficiaries). The idea is that relative wealth saved can be used as a proxy for reducing vulnerability as AFB funding will have a higher impact on relative wealth in less affluent countries with a more vulnerable population ${ }^{27}$.

Applying these indicators - Wealth Saved (absolute and relative) and Health Saved - to our sample of 16 AFB project proposals (see Table 4), we see that the cost-effectiveness indicators are not always contradictory as some projects perform very well according to several indicators. E.g. the Solomon Islands project leads the saved wealth ranking, both in absolute and relative terms, while the Ecuador project tops the health benefits ranking and ranks second in absolute wealth terms. Unfortunately, most project documents do not include data on health and absolute wealth benefits, and only refer to number of beneficiaries, from which approximate relative wealth savings can be derived. We assumed here that $7.5 \%$ of the wealth of targeted beneficiaries can be saved, if no details were given. This assumption is based on the median value $(7.7 \%$; the mean is $15 \%)$ of relative wealth savings calculated

\footnotetext{
${ }^{25}$ While utilitarianism would argue that Saved Wealth already incorporates social benefits, we can assume that the AFB has further social benefits in mind, e.g. equitable distribution and health.

${ }^{26}$ Actually, Stadelmann et al. (2011) propose to use environmental and cultural no-harm criteria to incorporate more of the social and environmental impacts but we omit the analysis of theses subindicator here for simplicity.

${ }^{27}$ An absolute wealth assessment treats $\$ 100$ of wealth increase for a millionaire and a subsistence farmer the same, while a relative assessment captures the relative importance of assets for coping with climate change much better.
} 
by dividing numbers for absolute wealth savings by beneficiaries and average per capita income in the country. Therefore, the most informative ranking can be made on the relative wealth indicator.

It has to be noted that the rankings depend on information provided in the project proposals. The proponent may have calculated the numbers using different assumptions and models. Reliable numbers would have to be based on common calculation methodologies or models, which are not available in case of the AF guidelines. Therefore, the ranking presented here does not necessarily correspond to the real cost-effectiveness; it only presents the information that was available to AFB members at the point of decision making.

Table 4: Ranking of Adaptation Fund projects according to cost-effectiveness indicators

\begin{tabular}{|c|c|c|c|c|c|c|c|}
\hline $\begin{array}{l}\text { Cost-effective- } \\
\text { ness indicator }\end{array}$ & \multirow{2}{*}{\multicolumn{2}{|c|}{$\begin{array}{c}\text { Saved Health } \\
\text { DALYs / k\$ }\end{array}$}} & \multirow{2}{*}{\multicolumn{2}{|c|}{$\begin{array}{c}\begin{array}{c}\text { Saved wealth - } \\
\text { absolute }\end{array} \\
\begin{array}{c}\text { \$ of income saved } \\
\text { (annually) } / \$\end{array}\end{array}$}} & \multirow{2}{*}{\multicolumn{2}{|c|}{$\begin{array}{c}\begin{array}{c}\text { Saved wealth - } \\
\text { relative }\end{array} \\
\text { No. of yearly } \\
\text { incomes saved / \$ }\end{array}$}} & \multirow{4}{*}{$\begin{array}{l}\text { Appro- } \\
\text { ved by } \\
\text { the } \\
\text { AFB? }\end{array}$} \\
\hline Measure & & & & & & & \\
\hline Source & \multicolumn{2}{|c|}{ Project documents } & \multicolumn{2}{|c|}{ Project documents } & \multicolumn{2}{|c|}{ Project documents } & \\
\hline & $\begin{array}{l}\text { Absolut } \\
\text { e Value }\end{array}$ & RANK & $\begin{array}{l}\text { Absolut } \\
\text { e Value }\end{array}$ & RANK & $\begin{array}{l}\text { Absolut } \\
\text { e Value }\end{array}$ & RANK & \\
\hline Belize & - & - & 2.0 & 3 & 0.5 & 10 & No \\
\hline Cook Islands & - & - & - & - & 0.1 & 13 & Yes \\
\hline Ecuador & 121 & 1 & 3.4 & 2 & 1.3 & 5 & Yes \\
\hline Egypt & - & - & & & 0.7 & 7 & Yes \\
\hline Eritrea & - & - & 0.3 & 8 & 0.6 & 8 & Yes \\
\hline Georgia & - & - & 0.4 & 5 & 0.1 & 12 & Yes \\
\hline Madagascar & - & - & - & - & 2.1 & 3 & Yes \\
\hline Mali & - & - & - & - & 2.3 & 2 & No \\
\hline Mauritania 1 & - & - & - & - & - & - & No \\
\hline Mauritania 2 & - & - & - & - & 1.9 & 4 & No \\
\hline Mauritius & - & - & 0.3 & 6 & 0.04 & 15 & Yes \\
\hline Papua New G. & - & - & - & - & 0.9 & 6 & No \\
\hline Samoa & - & - & - & - & 0.3 & 11 & Yes \\
\hline Solomon Islands & - & - & 6.5 & 1 & 4.4 & 1 & Yes \\
\hline Tanzania & - & - & 0.3 & 7 & 0.5 & 9 & Yes \\
\hline Uruguay & - & - & 0.7 & 4 & 0.05 & 14 & Yes \\
\hline
\end{tabular}


The correlation table (Table 5) indicates that the AFB has rather approved project proposals from countries with high absolute wealth savings, while projects with high relative wealth savings have been disadvantaged. The correlations of the Saved Health indicator rely on data from only one project, so it is not possible to make any general statement.

Table 5: Correlation between project approval \& cost-effectiveness criteria

\begin{tabular}{|l|c|l|l|l|}
\hline & Approval & $\begin{array}{l}\text { Saved } \\
\text { Wealth } \\
\text { absolute }\end{array}$ & $\begin{array}{l}\text { Saved } \\
\text { Wealth } \\
\text { relative }\end{array}$ & $\begin{array}{l}\text { Saved } \\
\text { Health }\end{array}$ \\
\hline Approval & 1.00 & & & \\
\hline Saved Wealth absolute & $0.44^{*}$ & 1.00 & & \\
\hline Saved Wealth relative & -0.14 & -0.05 & 1.00 & \\
\hline $\begin{array}{l}\text { Saved Health (data from } \\
\text { only 1 project!) }\end{array}$ & 0.20 & 0.39 & 0.20 & 1.00 \\
\hline
\end{tabular}

$\mathrm{N}=16$, Spearman rank-ordered correlation coefficients. ${ }^{*}=$ significant at 0.1 level, ${ }^{* \star}=$ significant at 0.05 level, ${ }^{* \star *}$ = significant at 0.01 level,

The analysis as just applied certainly has several limitations: we have omitted other potential cost-effectiveness criteria (e.g. environmental benefits) and the analysis relies on data from project documents, which are not rigorously verified.

\section{Equity and cost-effectiveness - are they friends or foes?}

Traditionally, equity and cost-effectiveness ${ }^{28}$ are seen as two principles or goals that are in contradiction and create trade-offs (Blank, 2002). Actually, there are two types of trade-offs between equity and cost-effectiveness (Le Grand, 1990): a value trade-off, so human beings may value one principle as normatively important and the other not ${ }^{29}$, and a production tradeoff, so a social outcome may be favourable from the perspective of one principle but not from the other.

\footnotetext{
${ }^{28}$ We will use the term cost-effectiveness (so policy effectiveness per costs) here, even if the literature about trade-offs with equity uses the terms "efficiency" (so economic benefits per costs).We can use this swap of concepts as the ideas / arguments are basically the same for both concepts.

${ }^{29}$ This value trade-off does not always exist: in the case of environmental policy making in the UK, Dietz and Atkinson (2010) found that respondents value both effectiveness and equity.
} 
In our case, we will focus on the production trade-off between equity and cost-effectiveness, so we examine whether specific outcomes of adaptation funding are equally favourable from an equity and cost-effectiveness point of view.

While Okun (1975) argues that there are substantial production trade-offs between equity and efficiency, we may argue that multilateral adaptation funding could be a case where the trade-off is low: First, the costs of administration and behavioural change due to equityrelated redistribution (Okun, 1975) are less relevant in the AFB context, as multilateral adaptation funding is by its nature a redistributive procedure from North to $\mathrm{South}^{30}$, so all the mentioned costs of striving for equity may, at least partially, also occur if the AFB strives for cost-effectiveness. Moreover, adaptation funding incorporates at least two types of redistribution, for which Blank (2002) expects low trade-offs: "transfers to populations with no capacity to change their behaviour"31 and subsidies for "commodities [...] that function as long-term investments and create future income gains ${ }^{32}$."

Finally, we may also question on a conceptual level whether equity and cost-effectiveness are necessarily contradictory in the context of multilateral adaptation funding. We have seen that many potential equity indicators somehow measure the "vulnerability" of countries. On the cost-effectiveness side, some indicators approximate "the reduction in vulnerability" to measure the effectiveness part of cost-effectiveness. Therefore, in many cases, the only difference between equity and cost-effectiveness indicators is that the equity indicators measure the potential for vulnerability reductions, while cost-effectiveness measures the actual vulnerability reduction achieved. In an extreme case, we even have "achieved reduction of vulnerability" both as equity and cost-effectiveness indicator, so there should not be any trade-off. This argument is similar to the one of Le Grand (1990) who argues that in some cases there is only seemingly a trade-off because "cost-effectiveness" itself is not the primary objective. Summing up our theoretical discussion, we may expect low trade-offs or even some synergies between equity and cost-effectiveness.

The level of trade-off will also certainly depend on the indicators chosen. Table 6 shows which pairs of indicators are likely to indicate trade-offs between equity and cost-

\footnotetext{
${ }^{30}$ It should be noted that many developing countries and scholars see adaptation funding more as "compensation" for losses due to greenhouse gas emissions of Northern countries.

${ }^{31}$ This example of Blank is similar to the argument of Fankhauser and Burton (2011) that building a minimum level of adaptive capacity everywhere ("equitably") may be an efficient way of spending adaptation funding.

32 In the adaptation case, several of such commodities with long-term benefits are subsidized (e.g. infrastructure investment, climate knowledge).
} 
effectiveness and which may indicate synergies. Starting with absolute wealth as costeffectiveness indicator, we may except likely trade-offs with all equity indicators: absolute wealth savings will likely occur in wealthier countries with low vulnerability, high income per capita and more dollars needed to make one person benefit from a programme. The second cost-effectiveness indicator, relative wealth, is likely to be in close correspondence with equity indicators. This is because relative wealth savings are more likely in poorer countries, which also tend to be more vulnerable (see correlations in Appendix $3^{33}$ ). Furthermore, as the relative savings indicator measures the number of personal livelihoods that can be saved, it should also be positively related to the number of beneficiaries. Finally, also in case of health benefits we may rather expect synergies with equity indicators as poorer and vulnerable persons are more at risk both regarding death and disability. As well, the number of beneficiaries should positively relate to the life years saved.

Table 6: Trade-off and synergies between indicators on a theoretical basis

\begin{tabular}{|c|l|c|c|c|}
\hline \multicolumn{2}{|c|}{} & \multicolumn{3}{|c|}{ Cost-effectiveness } \\
\cline { 2 - 5 } \multicolumn{2}{|c|}{} & $\begin{array}{c}\text { Absolute wealth } \\
\text { in USD }\end{array}$ & $\begin{array}{c}\text { Relative wealth } \\
\text { (livelihoods saved) }\end{array}$ & $\begin{array}{c}\text { Health benefits } \\
\text { (DALYs) }\end{array}$ \\
\hline \multirow{2}{*}{$\begin{array}{l}\text { Vulnerability index } \\
\text { (Barr et al., 2010) }\end{array}$} & Likely trade-off & Likely synergy & Rather synergy \\
\cline { 2 - 5 } & $\begin{array}{l}\text { Poorest countries } \\
\text { (GDP p.c.) }\end{array}$ & Likely trade-off & Likely synergy & Rather synergy \\
\cline { 2 - 5 } & Beneficiaries per USD & Likely trade-off & Likely synergy & Likely synergy \\
\hline
\end{tabular}

Table 7 displays how well the hypotheses made before are reflected by our sample of 16 projects submitted to the AFB in 2011. Regarding absolute wealth saved the expected tradeoff with vulnerability and poverty of a country is occurring. As well, consistent with our theoretical considerations, the relative wealth savings do positively correlate with all equity indicators. Finally, in case of health benefits, we see an unexpected trade-off with vulnerability and poverty but this result should be cautiously interpreted as it mainly relies on health savings mentioned by one project. Even when the sample size is small $(N=16$, often $\mathrm{N}=15$ due to missing data), some of the correlation coefficients are significant. The results for vulnerability are approximately the same for both the Barr et al. (2010) and the Global

\footnotetext{
${ }^{33}$ While poverty and vulnerability are distinct concepts, have different drivers and not all adaptation measures address both (Eriksen and O'Brien, 2007), there is substantial overlap in practice as lessaffluent people often suffer from wealth and wealth losses and have less capacity to recover (Kahn, 2005; Eriksen and O'Brien, 2007)
} 
Adaptation Institute (2011) vulnerability index, while the Buys et al. (2009) indicator shows correlation close to zero.

Table 7: Correlation between project approval \& cost-effectiveness criteria

\begin{tabular}{|c|c|c|c|c|c|}
\hline & \multicolumn{3}{|c|}{ Cost-effectiveness } \\
\hline & & & $\begin{array}{l}\text { Absolute wealth } \\
\text { in USD }\end{array}$ & $\begin{array}{l}\text { Relative wealth } \\
\text { (livelihoods } \\
\text { saved) }\end{array}$ & $\begin{array}{l}\text { Health benefits } \\
\text { (DALYs) }\end{array}$ \\
\hline & & & RANK & RANK & RANK \\
\hline \multirow{3}{*}{ 颃 } & $\begin{array}{l}\text { Vulnerabilit. } \\
\text { index (Barr et } \\
\text { al., 2010) }\end{array}$ & $\begin{array}{l}\mathrm{R} \\
\mathrm{A} \\
\mathrm{N} \\
\mathrm{K}\end{array}$ & $-0.57^{\star *}$ & 0.37 & -0.12 \\
\hline & $\begin{array}{l}\text { Poorest coun- } \\
\text { tries (GDP } \\
\text { p.c.) }\end{array}$ & $\begin{array}{l}\mathrm{R} \\
\mathrm{A} \\
\mathrm{N} \\
\mathrm{K}\end{array}$ & $-0.38^{*}$ & $0.53^{* *}$ & -0.24 \\
\hline & $\begin{array}{l}\text { Beneficiaries } \\
\text { per USD }\end{array}$ & $\begin{array}{l}\mathrm{R} \\
\mathrm{A} \\
\mathrm{N} \\
\mathrm{K}\end{array}$ & -0.10 & $0.71^{* * *}$ & 0.25 \\
\hline
\end{tabular}

$\mathrm{N}=15$, Spearman product moment correlation coefficients. ${ }^{*}=$ significant at 0.01 level, ${ }^{* *}=$ significant at 0.05 level, ${ }^{* * *}=$ significant at 0.1 level,

\section{Conclusions}

This paper has examined which equity and cost-effectiveness indicators could be used for selecting projects in multilateral adaptation funding. Furthermore, it has analyzed whether there are synergies or trade-offs between equity and cost-effectiveness. The theoretical analysis has been complemented by analyzing 16 project documents from the Adaptation Fund (AF) as major multilateral funding institution.

First of all, we have found it quite challenging to define universally acceptable equity and cost-effectiveness indicators, as neither the academic literature nor policy documents give clear guidance on when adaptation funding is equitable and cost-effective. We have selected three indicators for each principle that corresponds to both concepts in the literature (e.g. equality and leximin for equity; monetary and non-monetary benefits for cost-effectiveness) and to the scarce AF policy guidance (support for the most vulnerable; social, economic and environmental benefits). As equity indicators, we chose vulnerability, income level as proxy for poverty and number of beneficiaries per dollar. The cost-effectiveness indicators selected 
were economic savings absolute and relative as well as human lives saved, all per dollar of funding,

When applying these indicators to 16 adaptation fund projects, we find that the AFB has rather approved projects from high-income and less vulnerable countries with high absolute wealth savings, while not approving projects in poor, vulnerable countries with high relative economic savings. These patterns are clearly in contradiction with the final goal of the AFB to mainly support countries that are particularly vulnerable to climate change. It has to be noted that data constraints forced us to look at country level indicators, while we were not able to assess vulnerability at the community level, as demanded by the AFB project review criteria. Future analysis, both academic and conducted by the AFB, will have to address both the country and community/project level. Furthermore, we cannot guarantee that our assessment is valid beyond the particular equity indicators selected and analyzed. This is a particular relevant limitation as neither negotiators at the UNFCCC level nor the AFB have been able to agree on a set of indicators.

Regarding the relationship between equity and cost-effectiveness, our results show that there is not necessarily a high trade-off between the two, which can both be supported by theory and empirical data. From a theoretical point of view, we can argue that only a pure economic indicator for cost-effectiveness is probably in contradiction with equity principles, while other cost-effectiveness indicators based on human health and relative economic measures may be compatible with equity principles. To put it differently, if the definition of cost-effectiveness is simply to achieve a specific equity measure (e.g. reducing vulnerability of the poorest) at least costs, we would even see perfect synergies. Our ideas are supported by the data on the 16 analysed adaptation fund projects: while absolute economic savings are negatively correlated with vulnerability, poverty and number of beneficiaries, the relative economic measure, which is theoretically closer to vulnerability, is positively correlated to all of these three equity indicators.

Our results clearly have some limitations: first of all, we analyzed three easily understandable equity and cost-effectiveness indicators, which implied simplifications, neglecting of potentially relevant indicators and also value judgments. Therefore, it may be warranted to test the stability of our results by applying other or refined indicators for equity and costeffectiveness, while also analyzing further goals of adaptation finance (e.g. legitimacy ${ }^{34}$ ). Furthermore, we only applied our framework to 16 AFB projects. It would be interesting to

\footnotetext{
${ }^{34}$ For an overview of potential criteria for evaluating adaptation policies beyond economic efficiency, see Oberlack and Neumärker (2011) and Adger et al. (2005).
} 
see if the observed results are also valid beyond the AFB, including other bilateral and multilateral channels. As last limitation, the data availability and quality involves uncertainty, particularly on the cost-effectiveness side. Improving data quality would require elaboration of methodologies on how to measure the mentioned (or other) indicators. Such methodologies would also have to define whether development benefits beyond expected climate damages are included in the cost-effectiveness assessment. Given the limitations in data and human capacity, it will be a substantial challenge to develop meaningful but simple methodologies ${ }^{35}$.

What do our results imply for the operations of the AFB? First of all, the AFB may have to elaborate more detailed criteria for the technical review ${ }^{36}$, provide additional guidance to implementing entities on how to show compliance with these criteria, and make public the technical review and the reason for the final decision. While this may not have been very relevant in the past given the availability of sufficient funding, the AFB may have to be more selective in allocation of funding in the future (e.g. in the context of the $50 \%$ cap of funding to Multilateral Implementing Entities).

Second, if past approval decisions are related to the capacity of countries and implementing entities to develop well-written proposals, as discussed above, then capacity development for both National and Multilateral Implementing Entities, as well as the support for collection of relevant data, may be as important as deciding on concrete review and allocation criteria.

Third, the AFB may look for ways to find synergies between equity and cost-effectiveness, even when cost-effectiveness is defined in purely economic terms. Following the suggestions of Blank (2002), the AFB may consider the following areas as fruitful for potential synergies: interventions with long-term benefits (e.g. flexible infrastructure and information on climate change), creating adaptive capacity within communities and countries with low capacity and incentive-based systems ${ }^{37}$. Interestingly, most of these suggestions (flexibility, capacity and long-term orientation) are quite similar to the ones of Hallegatte (2009) and Fankhauser and Burton (2011).

\footnotetext{
${ }^{35}$ Such methodologies will not only have to cover the mean case but also a wide range of potential scenarios as timing, duration and extent of climatic hazards are often uncertain or unknown. 36 This step is already considered, see AFB (2011a)

${ }^{37}$ An incentive-based system creates incentives to socially desirable behaviour, e.g. conserving water, soil and protecting forests. As example, tradable water rights with initial equal per capita allocation would be such a incentive-based system that is both in accordance with equity (as each person has the same rights) and efficiency (as there are incentives to conserve water), see Rosegrant and Binswanger (1994), In practice, setting up the right legal and institutional frameworks alongside building social capacity will be required for successful implementation in developing countries (Bjornlund and McKay, 2002)
} 


\section{Acknowledgments}

We would like to thank Michel Köhler for contributing to the data analysis and Jan Cedergren, Farrukh Khan and Christoph Oberlack for valuable comments. Åsa Persson's participation in this paper was funded by the Swedish Research Council for Environment, Agricultural Sciences and Spatial Planning (Formas), grant no. 214-2009-992. For the analysis, Martin Stadelmann and Axel Michaelowa used data collected under a project financed by the Swiss Agency for Development and Cooperation (SDC). The contents of this paper do not necessarily reflect the opinions of the funding institutions. 


\section{References}

Adams, J., 1965. Inequity in social exchange. Advances in Experimental Social Psychology, 62. 335-43.

Adger, W.N., Arnell, N.W. and Tompkins, E.L., 2005. Successful adaptation to climate change across scales. Global Environmental Change-Human and Policy Dimensions, 15(2). 77-86. DOI 10.1016/j.gloenvcha.2004.12.005.

Adger, W.N., Agrawala, S., Mirza, M.M.Q., Conde, C., O'Brien, K., Pulhin, J., Pulwarty, R., Smit, B. and Takahashi, K., 2007. Assessment of adaptation practices, options, constraints and capacity. Climate Change 2007. Impacts, Adaptation and Vulnerability. Contribution of Working Group II to the Fourth Assessment Report of the Intergovernmental Panel on Climate Change, M. L. Parry, O. F. Canziani, J. P. Palutikof, P. J. Van der Linden, and C. E. Hanson (eds.). Cambridge University Press, Cambridge ; New York. 717-43.

AFB, 2010a. Project Level Results Framework And Baseline Guidance Document. AFB/EFC.3/3, Adaptation Fund Board secretariat, Washington D.C.

AFB, 2010b. Operational policies and guidelines for parties to access resources from the Adaptation Fund. . Adaptation Fund Board secretariat, City.

AFB, 2012. 10th AFB Meeting. http://adaptationfund.org/sites/default/files/AFB\%2010\%20Rev.1\%20final\%20report_9_7_10.pdf, accessed 6 March 2012.

AFB, The Adaptation Fund Project Review Process: Lessons Learned. Adaptation Fund Board Project and Programme Review Committee. Seventh Meeting. Durban, 12 December, 2011. AFB/PPRC. 7/3. accessed

AFB, 2011. 15th AFB Meeting. http://www.adaptation-fund.org/afb-meeting/1847, accessed 1st September 2011.

AFB, 2011. 13th AFB Meeting. http://www.adaptation-fund.org/afb-meeting/1709, accessed 25th February 2011.

AFB, Consideration of the $50 \%$ cap for proposals submitted by Multilateral Implementing Entities (MIEs). Adaptation Fund Board. Ethics and Finance Committee. Eighth Meeting. Bonn, 14 March, 2012. AFB/EFC.8/5/Rev.1. accessed

AFB, 2012. Adaptation Fund Project Review Criteria. http://www.adaptationfund.org/system/files/file/AF_Project\%20Review\%20Criteria.pdf, accessed 30th January 2012.

AFB, 2012. Request for Project/Programme Funding from Adaptation Fund. http://www.adaptation-

fund.org/system/files/file/AF_Request\%20for\%20Project_Programme\%20Funding.do c, accessed 30th January 2012 .

Ayers, J. and Dodman, D., 2010. Climate change adaptation and development I: the state of the debate. Progress in Development Studies, 10(2). 161-68. Doi $10.1177 / 146499340901000205$.

Barnett, J. and O'Neill, S., 2010. Maladaptation. Global Environmental Change-Human and Policy Dimensions, 20(2). 211-13.

Barr, R., Fankhauser, S. and Hamilton, K., 2010. Adaptation investments: a resource allocation framework. Mitigation and Adaptation Strategies for Global Change, 15. 843-58.

Bjornlund, H. and McKay, J., 2002. Aspects of water markets for developing countries: experiences from Australia, Chile, and the US. Environment and Development Economics, 7. 769-95. Doi 10.1017/S1355770x02000463.

Blank, R.M., 2002. Can equity and efficiency complement each other? Labour Economics, 9(4). 451-68.

Buys, P., Deichmann, U., Meisner, C., Ton That, T. and Wheeler, D., 2009. Country stakes in climate change negotiations: two dimensions of vulnerability. Climate Policy, 9(2009). 288-305. 
Costello, A., Abbas, M., Allen, A., Ball, S., Bell, S., Bellamy, R., Friel, S., Groce, N., Johnson, A., Kett, M., Lee, M., Levy, C., Maslin, M., Mccoy, D., McGuire, B., Montgomery, H., Napier, D., Pagel, C., Patel, J., Antonio, J., de Oliveira, P., Redclift, N., Rees, H., Rogger, D., Scott, J., Stephenson, J., Twigg, J., Wolff, J. and Patterson, C., 2009. Managing the health effects of climate change. Lancet, 373(9676). 1693-733.

Dellink, R., den Elzen, M., Aiking, H., Bergsma, E., Berkhout, F., Dekker, T. and Gupta, J., 2009. Sharing the burden of financing adaptation to climate change. Global Environmental Change-Human and Policy Dimensions, 19(4). 411-21.

Dietz, S. and Atkinson, G., 2010. The Equity-Efficiency Trade-off in Environmental Policy: Evidence from Stated Preferences. Land Economics, 86(3). 423-43.

Duus-Otterström, G. and Stripple, J., 2011. Justice and legitimacy in allocating adaptation resources. Paper presented at the ECPR Joint Session of Workshops, 12-17 april 2011, St. Gallen, Switzerland.

ECAWG, 2009. Shaping climate resilient development. A framework for decisionmaking. A report of the Economics of Climate Adaptation Working Group. ClimateWorks Foundation, Global Environment Facility, European Commission, McKinsey \& Company, The Rockefeller Foundation, Standard Chartered Bank and Swiss Re, San Francisco, Washington D.C., Brussels et al.

Eriksen, S., Aldunce, P., Bahinipati, C.S., D'Almeida Martins, R., Molefe, J.I., Nhemachena, C., O'Brien, K., Olorunfemi, F., Park, J., Sygna, L. and Ulsrud, K., 2011. When not every response to climate change is a good one: Identifying principles for sustainable adaptation. Climate and Development, 3(1). 7-20.

Eriksen, S.H. and O'Brien, K., 2007. Vulnerability, poverty and the need for sustainable adaptation measures. Climate Policy, 7(4). 337-52.

Fankhauser, S. and Tol, R., 1998. The value of human life in global warming impacts - a comment. Mitigation and Adaptation Strategies for Global Change 3. 87-88.

Fankhauser, S. and Burton, I., 2011. Spending adaptation money wisely. Climate Policy, 11(3). 1037-49.

Fearnside, P., 1998. The Value of Human Life in Global Warming Impacts. Mitigation and Adaptation Strategies for Global Change, (3). 83-85.

Fussel, H.M., 2010. How inequitable is the global distribution of responsibility, capability, and vulnerability to climate change: A comprehensive indicator-based assessment. Global Environmental Change-Human and Policy Dimensions, 20(4). 597-611. DOI 10.1016/j.gloenvcha.2010.07.009.

Global Adaptation Institute, 2011. Global Adaptation Index. http://gain.globalai.org/, accessed 9 November 2011.

Gupta, S., Tirpak, D., Burger, N., Gupta, J., Höhne, N., Boncheva, A., Kanoan, G., Kolstad, C., Kruger, J., Michaelowa, A., Murase, S., Pershing, J., Saijo, T. and Sari, A., 2007. Policies, Instruments and Co-operative Arrangements. Climate change 2007. Mitigation of climate change. Contribution of Working Group III to the Fourth assessment report of the Intergovernmental Panel on Climate Change, B. Metz, O. R. Davidson, P. R. Bosch, R. Dave, and L. A. Meyer (eds.). Cambridge University Press, Cambridge; New York. 745-808.

Hallegatte, S., 2009. Strategies to adapt to an uncertain climate change. Global Environmental Change-Human and Policy Dimensions, 19(2). 240-47.

Hinkel, J., 2011. "Indicators of vulnerability and adaptive capacity": Towards a clarification of the science-policy interface. Global Environmental Change-Human and Policy Dimensions, 21(1). 198-208. DOI 10.1016/j.gloenvcha.2010.08.002.

Horstmann, B., 2011. Operationalizing the Adaptation Fund: challenges in allocating funds to the vulnerable. Climate Policy, 11(4). 1086-96.

IMF, 2012. World Economic Outlook Database-September 2011. http://www.imf.org/external/pubs/ft/weo/2011/02/weodata/index.aspx, accessed 6th January 2012.

Kahn, M.E., 2005. The death toll from natural disasters: The role of income, geography, and institutions. Review of Economics and Statistics, 87(2). 271-84. 
Klein, R.J., 2009. Identifying countries that are particularly vulnerable to the adverse effects of climate change: an academic or a political challenge? Carbon and Climate Law Review, 3(3). 284-91.

Klein, R.J. and Möhner, A., 2011. The political dimension of vulnerability to the adverse effects of climate change. IDS Bulletin, 42(3). 15-22.

Kolm, S.-C., 1996. Modern theories of justice. MIT Press, Cambridge.

Le Grand, J., 1990. Equity Versus Efficiency - the Elusive Trade-Off. Ethics, 100(3). 554-68.

Leventhal, G., 1980. What should be done with equity theory? New approaches to the study of fairness in social relationships. Social exchange: Advances in theory and research, K. Gergen, M. Greenberg, and R. Willis (eds.). Plenum Press, New York. 27-55.

Lobell, D.B., Burke, M.B., Tebaldi, C., Mastrandrea, M.D., Falcon, W.P. and Naylor, R.L., 2008. Prioritizing climate change adaptation needs for food security in 2030 . Science, 319(5863). 607-10. DOI 10.1126/science.1152339.

Mendelsohn, R., 2000. Efficient adaptation to climate change. Climatic Change, 45(3-4). 583600.

Mill, J.S., 1863. Utilitarianism. Parker, son, and Bourn, London,.

Moench, M., Fajber, E., Dixit, A., Caspari, E. and Pokhrel, A., 2009. Catalyzing climate and disaster resilience. Processes for identifying tangible and economically robust strategies. Final Report of the Risk to Resilience Study. Institute for Social and Environmental Transition, Kathmandu.

Müller, B., 2008. International Adaptation Finance: The Need for an Innovative and Strategic Approach. EV 42. Oxford Institute for Energy Studies, Oxford.

Oberlack, C. and Neumärker, B., 2011. Economics, Institutions and Adaptation to Climate Change. Constitutional Economics Network Paper No. 04. 2011. University of Freiburg, Freiburg.

OECD, 2002. Glossary of Key Terms in Evaluation and Results Based Management. Organisation for Economic Co-operation and Development, Paris.

Okun, A., 1975. Equity and Efficiency: The Big Tradeoff. Brookings Institution Press, Washington D.C.

Paavola, J. and Adger, N., 2006. Fair adaptation to climate change. Ecological Economics, 56(4). 594-609.

Parfit, D., 1997. Equality and priority. Ratio, 10(3). 202-21.

Parry, M., Arnell, N., Berry, P., Dodman, D., Fankhauser, S., Hope, C., Kovats, S. and Nicholls, R., 2009. Assessing the costs of adaptation to climate change. A review of the UNFCCC and other recent estimates. International Institute for Environment and Development, London.

Parry, M.L., Canziani, O.F., Palutikof, J.P. and Co-authors, 2007. Technical Summary. Climate Change 2007. Impacts, Adaptation and Vulnerability. Contribution of Working Group II to the Fourth Assessment Report of the Intergovernmental Panel on Climate Change, M. L. Parry, O. F. Canziani, J. P. Palutikof, P. J. Van der Linden, and C. E. Hanson (eds.). Cambridge University Press, Cambridge ; New York. 23-78.

Persson, Å. and Remling, E., forthcoming. Equity and efficiency in international climate change adaptation finance: early experiences of the UNFCCC Adaptation Fund. SEI Working Paper.

Pielke, R., Prins, G., Rayner, S. and Sarewitz, D., 2007. Lifting the taboo on adaptation. Nature, 445(7128). 597-98. Doi 10.1038/445597a.

Ratajczak-Juszko, I. and Feaver, D., 2011. International climate finance: the equitable allocation of adaptation funding. Discussion paper, January 2011. RMIT University, Melbourne.

Rosegrant, M.W. and Binswanger, H.P., 1994. Markets in Tradable Water Rights - Potential for Efficiency Gains in Developing-Country Water-Resource Allocation. World Development, 22(11). 1613-25.

Solomon, S., Qin, D., Manning, M., Chen, Z., Marquis, M., Averyt, K.B., Tignor, M. and Miller, H.L., 2007. Climate change 2007. The Physical Science Basis. Contribution of 
Working Group I to the Fourth assessment report of the Intergovernmental Panel on Climate Change. Cambridge University Press, Cambridge ; New York.

Stadelmann, M., Michaelowa, A., Butzengeiger, S. and Köhler, M., 2011. Universal metrics to compare the effectiveness of climate change adaptation projects. Colorado Conference on Earth System Governance: Crossing Boundaries and Building Bridges, 17-20 May 2011, Colorado State University.

Stern, N., 2007. The economics of climate change. The Stern review. Cambridge University Press, Cambridge.

Thomas, D.S.G. and Twyman, C., 2005. Equity and justice in climate change adaptation amongst natural-resource-dependent societies. Global Environmental ChangeHuman and Policy Dimensions, 15(2). 115-24. DOI 10.1016/j.gloenvcha.2004.10.001.

Tol, R.S.J., Fankhauser, S. and Smith, J.B., 1998. The scope for adaptation to climate change: what can we learn from the impact literature? Global Environmental ChangeHuman and Policy Dimensions, 8(2). 109-23.

Tol, R.S.J., Downing, T.E., Kuik, O.J. and Smith, J.B., 2004. Distributional aspects of climate change impacts. Global Environmental Change-Human and Policy Dimensions, 14(3). 259-72. DOI 10.1016/j.gloenvcha.2004.04.007.

UNFCCC, 2010a. Synthesis report on efforts undertaken to monitor and evaluate the implementation of adaptation projects, policies and programmes and the costs and effectiveness of completed projects, policies and programmes, and views on lessons learned, good practices, gaps and needs FCCC/SBSTA/2010/5, United Nations Framework Convention on Climate Change, Bonn.

UNFCCC, 2010b. Potential costs and benefits of adaptation options: A review of existing literature. Technical paper. FCCC/TP/2009/2/Rev.1, United Nations Framework Convention on Climate Change, Bonn.

Wheeler, D., 2011. Quantifying vulnerability to climate change: implications for adaptation assistance. Centre for Global Development Working Paper 240, January 2011. Centre for Global Development, Washington DC.

WHO, 2010. Disability weights, discounting and age weighting of DALYs. http://www.who.int/healthinfo/global_burden_disease/daly_disability_weight/en/index. html, accessed 16th October 2010. 


\section{Appendices}

Appendix 1: List of projects in the sample

\begin{tabular}{|c|c|c|c|c|c|c|}
\hline Country & Name & $\begin{array}{l}\text { Fun- } \\
\text { ding }\end{array}$ & $\begin{array}{l}\text { Number } \\
\text { of bene- } \\
\text { ficiaries* }\end{array}$ & $\begin{array}{l}\text { Imple- } \\
\text { menting } \\
\text { agency }\end{array}$ & $\begin{array}{l}\text { Date of } \\
\text { Appro- } \\
\text { val }\end{array}$ & $\begin{array}{l}\text { Date of } \\
\text { docu- } \\
\text { ment }\end{array}$ \\
\hline & & $\begin{array}{l}\text { in } \\
\text { Mn \$ }\end{array}$ & $\begin{array}{l}\text { (direct / } \\
\text { indirect) }\end{array}$ & & $\begin{array}{l}\text { (all in } \\
2011)\end{array}$ & $\begin{array}{l}\text { (all in } \\
2011)\end{array}$ \\
\hline Belize & $\begin{array}{l}\text { Belize Marine Conservation and } \\
\text { Climate Adaptation Initiative }\end{array}$ & $\$ 10.0$ & 8000 & WB & $-0,1$ & Sep \\
\hline $\begin{array}{l}\text { Cook } \\
\text { Islands }\end{array}$ & $\begin{array}{l}\text { Strengthening the Resilience of our } \\
\text { Islands and our Communities to } \\
\text { Climate Change }\end{array}$ & $\$ 5.4$ & 6000 & UNDP & Dec & Sep \\
\hline Ecuador & $\begin{array}{l}\text { Enhancing Resilience of Communities } \\
\text { to the adverse effects of climate } \\
\text { change on food security }\end{array}$ & $\$ 7.5$ & 200,000 & WFP & Mar & Mar \\
\hline Egypt & $\begin{array}{l}\text { Building Resilient Food Security } \\
\text { Systems to Benefit the Southern } \\
\text { Egypt Region }\end{array}$ & $\$ 7.3$ & 100,000 & WFP & - & Sep \\
\hline Eritrea & $\begin{array}{l}\text { CC Adaptation Programme In Water } \\
\text { And Agriculture In Anseba Region, } \\
\text { Eritrea }\end{array}$ & $\$ 6.5$ & $\begin{array}{r}24,000 / \\
68,000\end{array}$ & UNDP & Mar & Mar \\
\hline Georgia & $\begin{array}{l}\text { Developing Climate Resilient Flood \& } \\
\text { Flash Flood Management Practices } \\
\text { To Protect Vulnerable Communities } \\
\end{array}$ & $\$ 5.3$ & 200,000 & UNDP & Dec & Sep \\
\hline $\begin{array}{l}\text { Mada- } \\
\text { gascar }\end{array}$ & $\begin{array}{l}\text { Promoting Climate Resilience in the } \\
\text { Rice Sector }\end{array}$ & $\$ 4.6$ & $\begin{array}{l}30,000 / \\
125,000\end{array}$ & UNEP & Dec & Sep \\
\hline Mali & $\begin{array}{l}\text { Programme Support for CC } \\
\text { Adaptation in the vulnerable regions } \\
\text { of Mopti and Timbouctou }\end{array}$ & $\$ 8.5$ & 400,000 & UNDP & - & Sep \\
\hline $\begin{array}{l}\text { Maurita- } \\
\text { nia (1) }\end{array}$ & $\begin{array}{l}\text { Coastal Weather and Climate Hazard } \\
\text { Early Warning System for Mauritania }\end{array}$ & $\$ 4.2$ & & WMO & - & Sep \\
\hline $\begin{array}{l}\text { Maurita- } \\
\text { nia }(2)\end{array}$ & $\begin{array}{l}\text { Enhancing Resilience of Commu- } \\
\text { nities to the Adverse Effects of Cli- } \\
\text { mate Change on Food Security }\end{array}$ & $\$ 10.0$ & 375,000 & WFP & - & Sep \\
\hline Mauritius & $\begin{array}{l}\text { Climate Change Adaptation } \\
\text { Programme In the Coastal Zone of } \\
\text { Mauritius }\end{array}$ & $\$ 9.1$ & 3,000 & UNDP & Sep & Sep \\
\hline $\begin{array}{l}\text { Papua } \\
\text { New } \\
\text { Guinea }\end{array}$ & $\begin{array}{l}\text { Enhancing adaptive capacity of } \\
\text { communities in Papua New Guinea to } \\
\text { climate change and disaster risks }\end{array}$ & $\$ 8.8$ & 152,000 & UNDP & - & Sep \\
\hline Samoa & $\begin{array}{l}\text { Enhancing resilience of coastal } \\
\text { communities of Samoa to climate } \\
\text { change }\end{array}$ & $\$ 8.7$ & 60,000 & UNDP & Dec & Sep \\
\hline $\begin{array}{l}\text { Solomon } \\
\text { Islands }\end{array}$ & $\begin{array}{l}\text { Enhancing resilience of commu-nities } \\
\text { to the adverse effects of CC in } \\
\text { agriculture \& food security }\end{array}$ & $\$ 5.5$ & 125,000 & UNDP & Mar & Mar \\
\hline Tanzania & $\begin{array}{l}\text { Implementation of Concrete } \\
\text { Adaptation Measures to Reduce } \\
\text { vulnerability of Livelihood ... }\end{array}$ & $\$ 9.8$ & 160,000 & UNEP & Dec & Sep \\
\hline Uruguay & $\begin{array}{l}\text { Buiding resilience to climate in } \\
\text { Vulnerable Smallholders }\end{array}$ & $\$ 7.0$ & $\begin{aligned} 1340 / \\
4500 \\
\end{aligned}$ & National & Dec & Mar \\
\hline
\end{tabular}

* Data on number of beneficiaries as stated in the project proposal documents are uncertain. There are no guidelines on how to estimate number of beneficiaries, including what minimum level of benefits or 'directness' of benefits to consider. 


\section{Appendix 2: Most vulnerable countries according to different indices}

\begin{tabular}{|c|c|c|c|}
\hline Country & $\begin{array}{l}\text { Overall vulnerability } \\
\text { index, rank }(1=\text { most } \\
\text { vulnerable })(n=131)\end{array}$ & $\begin{array}{c}\text { Vulnerability index, } \\
\text { (inverted) ranks } \\
(1=\text { most vulnerable) } \\
(n=187)\end{array}$ & $\begin{array}{c}\text { Impact vulnerability } \\
\text { index }(1=\text { most } \\
\text { vulnerable })(n=168)\end{array}$ \\
\hline & (Barr et al., 2010) & $\begin{array}{l}\text { (Global Adaptation } \\
\text { Institute, 2011) }\end{array}$ & (Buys et al., 2009) \\
\hline Belize & 78 & 87 & 4 \\
\hline Cook Islands & - & - & - \\
\hline Ecuador & 57 & 151 & 20 \\
\hline Egypt & 40 & 144 & 116 \\
\hline Eritrea & 3 & 36 & 14 \\
\hline Georgia & 101 & 126 & 63 \\
\hline Madagascar & 45 & 25 & 29 \\
\hline Mali & 30 & 13 & 65 \\
\hline Mauritania 1 & 8 & 19 & 1 \\
\hline Mauritania 2 & 8 & 19 & 1 \\
\hline Mauritius & 96 & 132 & - \\
\hline Papua New G. & 44 & 33 & 95 \\
\hline Samoa & 76 & 63 & - \\
\hline Solomon Islands & 56 & 28 & - \\
\hline Tanzania & 38 & 17 & 71 \\
\hline Uruguay & 128 & 170 & 87 \\
\hline
\end{tabular}

\section{Appendix 3: Correlation between approval and different vulnerability indices}

\begin{tabular}{|l|c|c|c|c|c|c|}
\hline & $\begin{array}{l}\text { approval } \\
\text { YN }\end{array}$ & $\begin{array}{l}\text { Vuln. Index } \\
\text { Barr (2010) }\end{array}$ & $\begin{array}{l}\text { Vuln. Index } \\
\text { GAl (2011) }\end{array}$ & $\begin{array}{l}\text { Vuln. Index } \\
\text { Buys(2009) }\end{array}$ & $\begin{array}{l}\text { GDP per } \\
\text { capita }\end{array}$ & $\begin{array}{l}\text { No. of be- } \\
\text { neficiaries }\end{array}$ \\
\hline approvalYN & 1.00 & & & & & \\
\hline $\begin{array}{l}\text { Vuln. Index } \\
\text { Barr (2010) }\end{array}$ & $0.44^{*}$ & 1.00 & & & & \\
\hline $\begin{array}{l}\text { Vuln. Index } \\
\text { GAI (2011) }\end{array}$ & 0.32 & $0.70^{* * *}$ & 1.00 & & & \\
\hline $\begin{array}{l}\text { Vuln. Index } \\
\text { Buys (2009) }\end{array}$ & 0.10 & 0.35 & 0.25 & 1.00 & & \\
\hline $\begin{array}{l}\text { GDP per } \\
\text { capita }\end{array}$ & 0.20 & $0.81^{* * *}$ & $0.82^{* * *}$ & 0.16 & 1.00 & \\
\hline $\begin{array}{l}\text { No. of be- } \\
\text { neficiaries }\end{array}$ & -0.36 & $-0.50^{*}$ & $-0.51^{*}$ & -0.10 & -0.50 & 1.00 \\
\hline
\end{tabular}

Spearman's rank-ordered correlation coefficients

${ }^{*}=$ significant at 0.01 level, ${ }^{* *}=$ significant at 0.05 level, ${ }^{* \star *}=$ significant at 0.1 level,

$\mathrm{N}=15$, except for Vuln. Index Buys $(\mathrm{N}=12)$ and GDP $(\mathrm{N}=16)$ 